
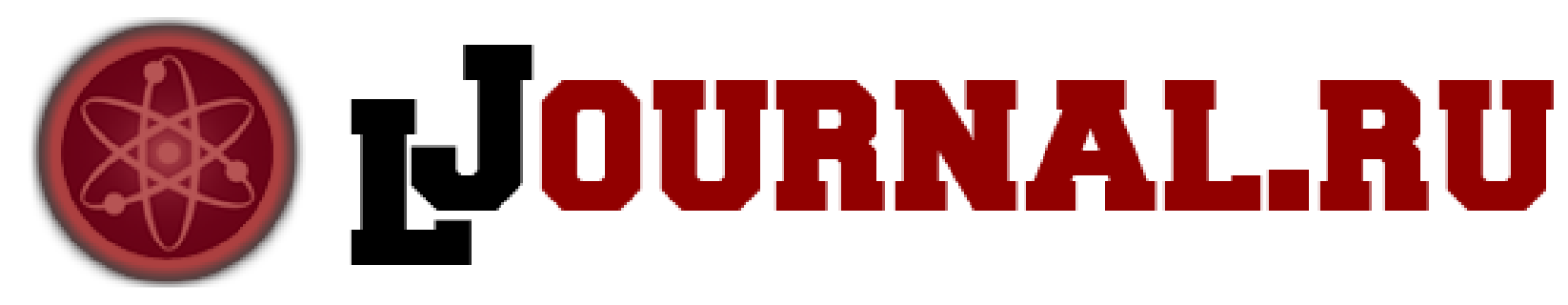

Таганова В.А. ${ }^{1}$, Пичхидзе С.Я. ${ }^{2}$, Артеменко А.А. ${ }^{3}$

${ }^{1}$ БИТИ (филиал) НИЯУ МИФИ

Россия, Балаково

${ }^{2}$ СГТУ им. Гагарина Ю.А.,

Россия, Саратов

${ }^{3}$ ЭТИ (филиал) СГТУ им. Гагарина Ю.А.,

Россия, Энгельс

doi: 10.18411/1j2016-2-26

\title{
Резина на основе токопроводящего технического углерода
}

Токопроводящая резина на основе сажи характеризуется высоким удельным сопротивлением и используется для обеспечения отвода статического электричества, а также для снятия статики в медицине, при изготовлении взрывчатых веществ, при использовании специального технологического оборудования [1].

Целью разработки является создание магнитного эластомера с токопроводящими свойствами.

Для решения поставленной цели нами предлагается нанесение на поверхность порошка $\mathrm{Nd}-\mathrm{Fe}-\mathrm{B} \quad 5 \%$ спиртового раствора 3 аминопропилтриэтоксисилана. После чего его высушивают при температуре 20 $25^{\circ} \mathrm{C}$ в течение 5 ч.

Технический результат достигается путём создания резиновых смесей, в которых в качестве наполнителя используется порошок $\mathrm{Nd}-\mathrm{Fe}-\mathrm{B}$ модифицированный 5\% спиртовым раствором 3 - аминопропилтриэтоксисилана и технический углерод N 330.

Изготавливалась резиновая смесь на основе бутадиен-нитрильного 
каучука, табл.1. В указанную резиновую смесь вводился порошок $\mathrm{Nd}-\mathrm{Fe}-\mathrm{B}$ в количестве 200-400 масс. ч., модифицированный 5\% спиртовым раствором 3аминопропилтриэтоксисилана и технический углерод N 330.

Наполнители вводились в резиновую смесь на вальцах ПД 320 при нулевом зазоре. Образцы для испытания вулканизовали в гидравлическом прессе «Monsa», Италия при температуре $175^{\circ} \mathrm{C}$ в течение 10 мин. и давлении 3,5 МПа. Было получено 4 смеси с различным содержанием порошка $\mathrm{Nd}-\mathrm{Fe}-\mathrm{B}$ и технического углерода $\mathrm{N}$ 330. Составы исследованных резиновых смесей приведены в табл. 1.

Испытывались образцы шириной $(25 \pm 0,5)$ мм, толщиной $(2,0 \pm 0,2)$ мм и длиной 115 мм. Испытания проводили на разрывной машине Zwick/Roell co скоростью перемещения подвижного захвата 100 мм/мин.

При введении магнитного наполнителя в резиновую смесь крутящий момент существенно возрастает. В большей степени увеличение разности крутящих моментов MH-ML характерно для резин, содержащих модифицированные органосиланами порошки. Предполагаем, что магнитный порошок выступает в роли вторичного катализатора, способствующего дополнительному образованию связей между макромолекулами каучука, и оказывающего влияние на взаимодействие наполнитель-эластомер. В большей степени это проявляется для модифицированных порошков. Таким образом, рост крутящего момента при введении магнитного наполнителя связан не только с вырастанием вязкости, но также с образованием дополнительных поперечных связей.

Анализ результатов показал возможность применения порошка $\mathrm{Nd}-\mathrm{Fe}-\mathrm{B}$, модифицированного 5\% спиртовым раствором 3- аминопропилтриэтоксисилана и технического углерода N 330 для производства магнитных, токопроводящих эластомеров. При этом физико-механические и технологические характеристики магнитных, токопроводящих эластомеров на основе бутадиен-нитрильных каучуков соответствуют норме. 
Использование разработанной токопроводящей резины с приведенными магнитными свойствами позволяет избежать применение токопроводящего клея, который необходим для крепления эластомера к металлическим поверхностям.

Физико-механические показатели заявляемой резиновой смеси представлены в табл. 2.

Таблица 1

Составы исследованных резиновых смесей

\begin{tabular}{|c|c|c|c|c|c|}
\hline \multirow{2}{*}{$\begin{array}{l}\text { № } \\
\Pi / \Pi\end{array}$} & \multirow{2}{*}{ Состав } & \multicolumn{4}{|c|}{ Содержание ингредиентов в составах, масс. ч. } \\
\hline & & Исход-ная & 1 & 2 & 3 \\
\hline 1 & Каучук БНКС-18АМН & 80,00 & 80,00 & 80,00 & 80,00 \\
\hline 2 & Каучук БНКС-28АМН & 20,00 & 20,00 & 20,00 & 20,00 \\
\hline 3 & Sulfenax CBS/MG & 1,50 & 1,50 & 1,50 & 1,50 \\
\hline 4 & Ekaland DTDM PD & 1,50 & 1,50 & 1,50 & 1,50 \\
\hline 5 & Dimacit TMTD & 1,80 & 1,80 & 1,80 & 1,80 \\
\hline 6 & $\begin{array}{l}\text { Углерод технический N } 330 \\
\text { модифицированный }\end{array}$ & 65,87 & 65,87 & 65,87 & 65,87 \\
\hline 7 & Масло-мягчитель «ПМ» & 0,40 & 0,40 & 0,40 & 0,40 \\
\hline 8 & Duslin $\mathrm{P}$ & 0,13 & 0,13 & 0,13 & 0,13 \\
\hline 9 & Белила цинковые БЦО М & 5,00 & 5,00 & 5,00 & 5,00 \\
\hline 10 & Кислота стеариновая, Т-32 & 1,50 & 1,50 & 1,50 & 1,50 \\
\hline 11 & Dusantox IPPD & 2,50 & 2,50 & 2,50 & 2,50 \\
\hline 12 & Пластификатор ДОФ & 21,60 & 21,60 & 21,60 & 21,60 \\
\hline 13 & Церезин 80 & 5,00 & 5,00 & 5,00 & 5,00 \\
\hline 14 & Perkacit NDBC & 1,50 & 1,50 & 1,50 & 1,50 \\
\hline 15 & Порошок Nd-Fe-B & 200 & 200 & 400 & 400 \\
\hline 16 & 3- аминопропилтриэтоксисилан & - & 0,40 & - & 0,40 \\
\hline & $\mathrm{M} \min , \mathrm{N} \cdot \mathrm{m} * *$ & 2,23 & 1,96 & 2,73 & 2,66 \\
\hline & Т 2, мин. & 0,43 & 0,44 & 0,44 & 0,44 \\
\hline & Т 50, мин. & 0,70 & 0,72 & 0,73 & 0,76 \\
\hline & Т 90, мин. & 1,47 & 1,71 & 2,25 & 2,38 \\
\hline & $\mathrm{M} \max , \mathrm{N} \cdot \mathrm{m}$ & 14,00 & 23,37 & 31,25 & 44,01 \\
\hline
\end{tabular}

Таблица 2

Физико-механические показатели магнитных эластомеров

\begin{tabular}{|l|c|c|c|c|}
\hline \multicolumn{1}{|c|}{ Показатель } & Исходная & \multicolumn{3}{|c|}{ Составы магнитных эластомеров } \\
\cline { 3 - 5 } & 1 & 2 & 3 & 4 \\
\hline Твердость по Шор А, в пределах & 63 & 56 & 70 & 65 \\
\hline $\begin{array}{l}\text { Условная прочность при растяжении, кгс/см² } \\
\text { менее не }\end{array}$ & 32 & 49 & 53 & 64 \\
\hline $\begin{array}{l}\text { Относительное удлинение при разрыве, \%, не } \\
\text { менее }\end{array}$ & 270 & 300 & 290 & 300 \\
\hline Сопротивление раздиру, кг/см в пределах & 17 & 29 & 19 & 30 \\
\hline $\begin{array}{l}\text { Удельное объемное сопротивление при } \\
\text { напряжении 100 V, Ом·см }\end{array}$ & 2,1 & 2,1 & 1,3 & 1,3 \\
\hline Магнитная энергия $B_{r}$, Тл, не менее & 0,20 & 0,20 & 0,29 & 0,29 \\
\hline
\end{tabular}




\section{Литература:}

1. Оптимизация состава и свойств магнито-эластомерных композиций на основе фторкаучука СКФ-26 [Текст] / В. А. Таганова, С. Я. Пичхидзе, В. С. Юровский // Каучук и резина. - 2012. - № 4. - С. 23-26 